
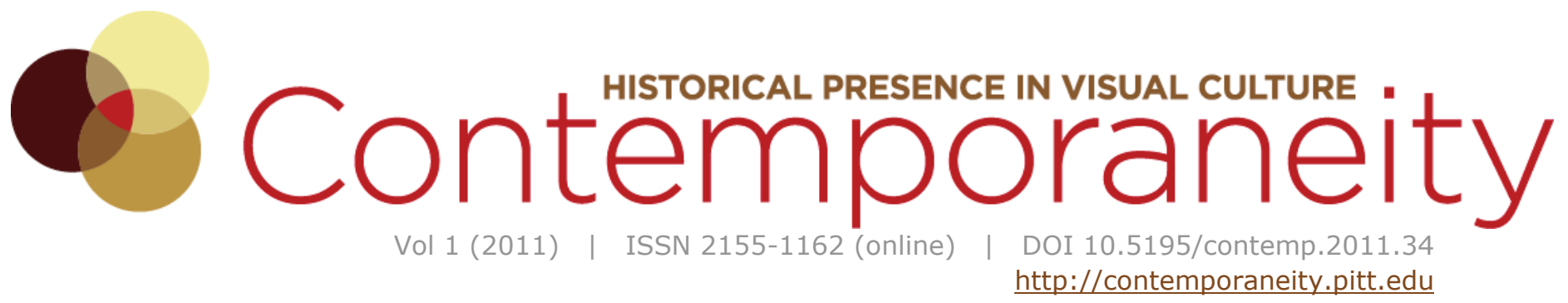

\title{
The Temporalities of Soviet and Postcommunist Visual Culture Boris Groys and Petre Petrov in Conversation
}

Robert Bailey and Cristina Albu

\begin{abstract}
This discussion took place on April 21, 2010 in the Humanities Center at the University of Pittsburgh. Over the course of two hours, we, Robert Bailey and Cristina Albu, posed to Boris Groys and Petre Petrov a series of questions about temporality and visual culture in the Soviet Union, contemporary Russia, and other formerly communist countries in Eastern Europe. Our hope was to identify the paradoxical instances when multiple temporalities coexist or compete for control of time, or where different forces impose their respective narratives, chronologies, or histories on the same moments and events. We are grateful to Professors Groys and Petrov for their careful and considered answers to our questions. Thanks are also due to Professors Jonathan Arac and Todd Reeser at the Humanities Center for facilitating the discussion, as well as to Contemporaneity editors Heidi Cook, Amy Cymbala, and Rachel Miller for their help with transcription.
\end{abstract}

\section{About the Authors}

Boris Groys is Global Distinguished Professor of Russian and Slavic Studies at New York University. Petre Petrov is Assistant Professor of Slavic Languages and Literatures at Princeton University. Robert Bailey and Cristina Albu are editors of Contemporaneity. 


\section{The Temporalities of Soviet and Postcommunist Visual Culture}

\author{
Boris Groys and Petre Petrov \\ in Conversation
}

\author{
Robert Bailey and Cristina Albu
}

This discussion took place on April 21, 2010 in the Humanities Center at the University of Pittsburgh. Over the course of two hours, we, Robert Bailey and Cristina Albu, posed to Boris Groys and Petre Petrov a series of questions about temporality and visual culture in the Soviet Union, contemporary Russia, and other formerly communist countries in Eastern Europe. Our hope was to identify the paradoxical instances when multiple temporalities coexist or compete for control of time, or where different forces impose their respective narratives, chronologies, or histories on the same moments and events. We are grateful to Professors Groys and Petrov for their careful and considered answers to our questions. Thanks are also due to Professors Jonathan Arac and Todd Rieser at the Humanities Center for facilitating the discussion, as well as to Contemporaneity editors Heidi Cook, Amy Cymbala, and Rachel Miller for their help with transcription.

Robert Bailey: Despite the avant-garde's claim to a kind of vanguardism, few Russian avant-garde artists actively participated in the Russian Revolution. There seems to have been a disconnection between the artistic and political vanguards in Russia in 1917. Why is this so?

Boris Groys: The revolutionary organizations were all underground terrorist organizations and secret societies, so if you are an artist and you are part of one of these groups you are completely disconnected. Maxim Gorky had some connection to them, and a very famous example was Boris Savinkov. He was a writer and a terrorist at the same time, but these are fundamentally two exceptions. After the revolution, the whole thing became open and others joined.

Petre Petrov: The question is a bit tautological. The avant-garde is vanguardist, of course, by virtue of its name, but it is a different kind of radicalism. It's clear that, if the question is why didn't the avant-garde artists storm the Winter Palace, then the answer is the one Boris gave. Not just in Russia, but everywhere, these artists were not active participants in the political movements, which is not to say that later they did not hang their hopes on some of these movements. These stories are well known. In Italy, Germany, and Russia, there were cultural radicals who saw hope in these large social upheavals and their consequences, and they saw, in some of them, the fulfillment of the projects that they envisioned; but clearly these are two completely different phenomena. And if you look from the perspective of the Bolsheviks, as they saw the cultural vanguard, you will immediately understand why these two movements could not have had much in common. For the Bolsheviks, this was simply the froth of what is essentially bourgeois or petit bourgeois life that rises to have imaginary revolts in an imaginary sphere of artistic experimentation.

BG: I think the most interesting example is the example of Italian futurism because Italian Futurism constituted itself in the beginning as a political movement and collaborated with the fascist movement from the beginning. They were preceding, in a certain way, Mussolini's movement, but we should not forget that Italy was a chaotic and open society at the same time. Russia was a very closed society where radical oppositional politics were a part of the underground. So this kind of collaboration was not possible, but in principle of 
course you have some movements, and I think Italian Futurism is the best example of that, where aesthetic radicalism and political radicalism coincide, so that happens too.

PP: A more interesting question is whether one can think of Bolshevik radicalism and artistic radicalism as arising from some general situation, which feeds them both and yet occasions very different responses. This is quite possible to conceptualize. Obviously, Russia at the beginning of the twentieth century is a place of enormous social and economic upheavals, and that cannot but be the fuel both for political movements and for the rethinking of artistic means or the rethinking of art as such. But clearly these are vectors that move on different planes even if they have the same historical substratum, broadly speaking.

Cristina Albu: So how do these two projects become tangential after the revolution?

BG: After the revolution, the Bolshevik party tried to initiate a large-scale communist cultural politics, and the whole traditional intelligentsia did not want to cooperate because the traditional Russian intelligentsia was on the side of liberal movements of different kinds and did not accept Bolsheviks. But at that time, the first period of development, the avantgarde was simply one exception, simply because people were ready to cooperate. It was a small part, but everybody else did not want to cooperate.

PP: And on the side of the left avant-garde, clearly there was, for a while, the hope that these vectors will meet, that what has started as a very messy affair of bloodshed and repression may become spiritualized to a point where it meets the pursuit of new forms or even some kind of art beyond art. Boris has written quite well about this: the politicization of aesthetics and the aestheticization of politics are two movements that in principle could find a meeting point, whether they do or not and how this happens, this is a complex question, but it is a fact of history that the avant-garde in Russia did lend a hand to the political regime for most of the 1920s. They tried to represent to themselves and to their audiences the social movement as something that is in continuum with their pursuits in the artistic sphere.

CA: So it is something that has very much to do with the internal dialectics of the avantgarde approach and the different positions that existed within the avant-garde?

BG: There were different positions, but in general, you have a kind of vacuum, and you can project into this vacuum your dreams of a new beginning, a point zero. And from this point zero, you have the new perspective to move on. Of course, every artist wants to erase history, to be the point of beginning, so it is a tautology of art.

PP: The beginning is different for the people with the guns and the people with the easel and paintbrush. The first want to change reality per se. It begins with nationalization and the shooting of enemies of the people. For the people with the brushes, it begins with creating a kind of universal language, a kind of form that, from the ideal realm, will redeem the material realm. It is really a movement from two opposite directions that was seen, on the side of the artists, as one movement. But the people in power really never had any illusions about this, even if they did seek the support of leftist poets like Vladimir Mayakovsky or artists like Pavel Filonov or Kasimir Malevich. On the side of the rulers, this rapprochement was much more pragmatic, and they never embraced the radical imaginings (and imagings) of the left avant-garde. 
CA: Perhaps we can move on to the next question. The avant-garde aims to realize a utopian fantasy in a dialectical manner by negating the past in order to bring about the future, much like the socialist project of Stalin, and yet avant-garde art is deemed inappropriate for Soviet socialism on the grounds that it is not accessible to a mass audience - precisely because the features it shares with socialism require explanation. Except for the overly didactic aspects of socialist realism, what inherent qualities does socialism possess to explain itself? We have realism as form and socialism as content, but do we need a metatext to explain this?

BG: First of all, it was the idea of Clement Greenberg that the avant-garde was rejected because it was not understood by the masses. The point was never raised in discussions of the 1920 s or 1930s. It was invented by Greenberg. So if you look at the literature of the time, you will not meet this point at all. And then, if you look at Russian avant-garde movements at that time, for example LEF, operating with very simple text, propaganda text; Окна Роста, Rosta windows; Gustav Klutsis and Alexander Rodchenko with photography -- it was all absolutely obvious for everybody. It was also obvious for the masses. And if you look for example at the Proletkult movement, they have a huge mass of visual and literary production, which was absolutely accessible to the people. So this explanation is completely wrong, simply wrong.

A completely different point to do with art of the past. The demise of the avant-garde begins in the end of the 1920s, in terms of rescuing and appropriating the art of the past. That was a topic, and it was the only one, too. Restoring the museums, restoring the Hermitage, reediting the classics, making translations from the Western classics, introducing these texts and introducing these images in the school process and the university process. So, this type of retribution, because in the 1920s you do not have that - the Hermitage is closed. So you have this huge process of the reoccupation of the past, and this process was the starting point of the criticism of the avant-garde.

A second point, interconnected with that, is that the Soviet power wanted to be proud of its art, and they simply saw the Russian avant-garde as art of low quality. It was simply like that. They did not believe that it was good art. These squares and triangles and unclear poetry and so on and so on -- they see that as low, low, low, low art, actually nearer to the masses. What they wanted to do is to compare their own art to the highest achievements, and that is Stalin's big point. Time and again: "We have to create art at the level of the highest achievements of human history." And that is of course Rembrandt, that is Verdi, that is this, that is that. It is Tolstoy. It is not this avant-garde stuff because this stuff is simply bad. If you look internationally at this time, it was the same position with Mussolini, who at a certain point in time decided that Futurism was simply bad and we have to go back to neoclassicism. The return to order in France. The rise of Neue Sachlichkeit in Germany. And when you look at the Soviet magazines of that time, they quote all that. So they felt themselves completely justified by the international art situation at that time. They saw the avant-garde as a kind of a certain mistake that is actually over and the people who actually kept on with these ideas have become retrograde. If you look at publications of that time, they said, "Such reactionary people as Malevich, making art of the 1910 s and 1920s, completely misunderstand the international art scene of today." From the perspective of cultural politics in Russia during the Stalinist period of the 1920s and 1930s, they really wanted to create a great, true, high level art. And they accepted also people who were very problematic in terms of ideology like Bulgakov, like Pasternak, who wrote at that time. There are others; it is very complicated. And they introduced huge programs to educate the Soviet population in listening to Tchaikovsky, reading Tolstoy, listening to Verdi, looking at Rembrandt. So it had nothing to do with respect for the masses. It is a complete illusion to think so. It was a reeducational program to put Russian culture on an appropriate level believing that the avant-garde is simply low-level art, low-quality art. 
PP: The triangles did not strike them as comprehensible, that is for certain. They did want, of course, a kind of art that would be accessible, but this is not the only reason for the rejection of the avant-garde. Much of what Boris said is correct. I would have to take issue with the formulation of the question, which states that Stalinism rejects the past. It does exactly the opposite. Stalinism is the appropriation of the past; it is the museum of the past. Without it the Stalinist project is completely unthinkable. In light of this, the rejection of modernism becomes quite comprehensible. So modernism is rejected not only because it is incomprehensible. It is rejected because it is idealistic. From a socio-historical point of view, this is an art that corresponds to the moment of the rotting of the bourgeois order.

BG: Absolutely. It's seen as decadent.

PP: Indeed, yes. And from that point of view, it has to be rejected because the art appropriate for where we are now, namely, the coming of socialism, is the art of a socialist world. The 1920 s and much of the 1930 s are spent in trying to figure out what is this form of creativity that would correspond to the advance of socialism, and the Soviet leadership never had any illusions that modernism could somehow transform itself into that art of the very near future. Let us look at this whole group of people who remained after the revolution and consented to one extent or another to serve the regime, let us look at them with the eyes of the regime. They were very much on the level of those so-called bourgeois specialists in industry, in science, and in administration, who were there to provide the skill, the skill divorced from any of the spiritual baggage that comes along with it. Once the skill is there, once it is being taught, once it is being handed over, they become dispensable if they have not been transformed into true Soviet citizens. The new cadres will come, take these skills, and put the new content into them.

BG: That is precisely why the avant-garde failed: because there were no skills. They did not see the avant-garde as having any skills. Stalin, if we speak about the arts and sciences, says we have to take everything that is best and that was created by human history and betray it by moving further. So, for them, the avant-garde was a bourgeois betrayal of the patrimony of humankind that should be saved by socialism. And already, in the Russian revolution, Trotsky says that the great mistake of the avant-garde is to think that the avantgarde is a break with the past. A revolutionary artist should always see himself as living through the revolutionary heritage because the revolution begins already in Egypt and goes through the whole period of history. All the dreams of the oppressed people, all the dreams of liberation, go through thousands of years of human history, expressed by different kinds of art. All of them are actually our tradition. The revolution has its own tradition. It is not a break with tradition. And Trotsky says that is the difference between art and the artistic avant-garde because the artistic avant-garde tries to initiate art by rejecting tradition, and he wants to fulfill it. We want to be at the end of the tradition, at the end of the revolutionary struggle for the life of humankind.

PP: The word "fulfillment" should be heavily underlined every time you address the culture of Stalinism. This is the key concept for understanding what happens from the early thirties on. It is this sense that history is being fulfilled, that here and now in the Soviet Union, some kind of moment of fruition for the entirety of human history is taking place. Within that concept, every kind of fruition must take place, including in the artistic domain. Therefore, as much of the past as is permissible has to be secured.

CA: But there were certain things from the past that were selected and appropriated. Of course, the artworks from the past that best matched the Soviet project were the ones appropriated and their meaning was translated in socialist terms. Yet, except for the fact that 
the avant-garde was associated with a lack of skill as you mentioned, was it not also problematic to incorporate because it lacked content appropriate for the socialist project?

BG: Well, it is not a lack of content. The point is that ideology during Stalin's time was based on a short text of Lenin's about culture where he says that culture as such does not exist. There are two cultures: one for the oppressed classes and one for the oppressing classes. And looking at the past we have to decide what is the patrimony of the oppressed classes and what is the patrimony of the oppressing classes. Now, if you look at the Russian avant-garde, it appeared in the context of the oppressing classes. It does not differentiate itself from the art of the West and from the bourgeois art as it is practiced in Paris and New York and other places. So it is quite clear that it is the art of oppression. If you look for example at the famous - I think it was the middle of the 1920 s - the famous exhibition of modernist art - I think it was in the Hermitage - under the title "Art History in the World of Capitalism" or something like that, you have two parts of it: the art of financial capitalism and it is impressionism and expressionism, and the art of industrial capitalism and there is constructivism. So if you look at that, then it is obvious that the avant-garde, and even the Impressionists, were seen as the patrimony of the oppressive classes. So what kind of lesson do you draw from that?

PP: And, of course, they were right. There is no denying that modernism participates in a particular dynamic that has to do with modernity and a particular moment in modernity when art becomes completely detached from whatever had been its social moorings before; now it has to realize that it is a commodity like anything else and it has to revolt against that. So modernism is very much a part of this critical phase in the life of art at the beginning of the twentieth century. It could have been understood in those terms, and the Soviets very much saw it in that way: as a kind of infantile revolt within the bourgeois family, just as, for example, romanticism could be seen as an earlier revolt against the disappointments following the great revolution of the eighteenth century. Soon after the great revolutionary upheaval, the prose of bourgeois life sets in, so certain hotheads begin to think of themselves as extremely radical artists and existential misfits, while in fact they are very much in the mainstream of bourgeois culture, as a leftist historian would write the history of that culture. Something similar happens at the later juncture, when modernism begins its revolt against the bourgeois order.

RB: Let's focus on the question of the Stalinist present. Stalinism relies on two temporalities both rooted in Hegel: a dialectical movement towards the absolute, which is the socialist project of realizing socialism, but also the notion of an end of history, which names what happens after the absolute is realized. The latter is subject to a kind of an internal bifurcation. It's always postponed into the distant future. We haven't gotten there yet. It's a project to be realized. And it has simultaneously already been realized in the revolutionary past. So between this kind of dialectical progressivism and the end of history, the Stalinist present seems to disappear. It either becomes the past or it becomes the future. What happens to the present under Stalinism?

BG: The present is of course the point of struggle and conflict between the powers of the future and the powers of the past. Our goal is to take the right position in the struggle. We have to punish people for taking the wrong position. So, it's an area of conflict.

PP: We can think of it in the following way. I am reminded of this thing that Ilya Ehrenburg said at the First Congress of the Union of Soviet Writers. He was addressing the audience, and there were of course all of those people who had come from abroad, famous writers of a leftist bent. He spoke of the Soviet Union. Turning to them, he said, "You have 
arrived in the future. You have been in a time machine." The present of the Soviet Union is the future of the rest of the world, especially the communist movement. What I find extremely interesting is how, in Ehrenburg's words, time is plastered over space, so that space itself is temporalized into different zones. And it is not only on the international scale that we have spaces of the future and spaces of the past, or the not-yet-future. If we look at the Soviet Union itself, within the internal cultural geography, something like that happens as well: Moscow is the future to which every other space looks. If we make sense of this spatialization of time, we could start thinking about what the present is within Stalinism. Again, I have to reemphasize the keyword of fulfillment. The present is a time of flowering and growth. It is a time when the past is collected - we spoke about this - and in which the fruits are already visible of that which for the 1920s was a distant future, but now it is not that distant. It is around the corner. Already in the 1930s, socialism is essentially realized in its foundations. What we need to see is simply how these foundations naturally follow up to the roof. But all of that is already prefigured in the foundations. It is there. You only need to feel that it is there. With Stalin's idea of socialism in one country this whole vision is already implicitly in place. "Socialism in one country" - meaning there is one place in the world where socialism has come to be. It has grown up and is flowering right now. If you look at it in the context of the Third International, every other space is simply located in a progression towards what is here and now already happening in Russia.

BG: That is true, but at the same time, Stalin has never considered the Soviet Union as a landscape or its space as being a landscape. He always considered it as a territory of extreme struggle, and Stalin always said that, if we were moving towards communism, the class struggle intensifies. So this new world is there, but the old world is also there. It's like how the place of Satan is in the church. You have the church as a profane space. Capitalism is a profane space. The profane space is profane for good and for Satan. Satan is not interested in the profane space. He is interested in seducing and diverting the saints and the priests toward the real vocation and turning their mass into black mass. And that is what precisely people like Alexey Rykov and Nikolai Bucharin did. If you do not understand this possibility, this duality, and this belief that precisely the Soviet Union is a place of the most radical anti-Soviet temptation, then you cannot understand the whole repressive logic of the Stalinist regime based on a nostalgic intuition that this place, being the best place, is at the same time the most endangered place.

PP: I don't think we are contradicting each other. The idea of the devil in the church is a clever one. A very effective way of putting it, definitely: the essential intuition for Stalinism is that the devil is of course attracted to the most holy. The presence of the devil in a way confirms that we are in the presence of the most holy. The devil does not go into dilapidated parish churches. It goes to the Kremlin. The presence of the enemy confirms that we are almost there. We have basically arrived. The doctrine of the intensification of class struggle is precisely this. It is that, exactly at the moment when the hostile classes are defeated, they become most hostile, most deleterious to the regime, because they are in a way already choked. The spasmodic reactions are most violent at that point. Of course this Manichean struggle is there, but it is interesting how this idea of the devil or the enemy within us, or the saboteur, or the kulak, or all those different vermin of Stalinism - how that in itself is already an ideological tenet that reinforces the idea that socialism is essentially already constructed.

CA: In your respective work, both of you privilege the power of language in the constitution of the Stalinist project. But what is Soviet language: how does the static structure of langue represented by Soviet ideology relate to the dynamic praxis of parole? How can parole develop in the Soviet context? Moreover, does this emphasis on language obscure the role of the visual within Stalinism? Regardless of the power of language in 
Stalinist culture, the visual retains a significant role. What is the distinct power of the Stalinist image, and how does it relate to language?

BG: Obviously, there is emancipation of the image in the West. In Russia at the beginning of the twentieth century, that didn't take place. So you don't have the phenomenon of an autonomous image. The image is subjected to a certain kind of narrativity. This narrative is ideological. Being powerful or not, under the Stalinist regime, the image was never really autonomous in relationship to its content, to its narrative function. It was always in a certain way an illustration to something. It was never really completely liberated from this function. That is why Stalinist culture remains ultimately language dominated.

PP: Definitely. You can easily trace from the late 1920s into the early 1930s this process whereby the text is installed as the central element of cinema, with the emphasis on the script. But also in painting with the return to the $19^{\text {th }}$ century, to the narrative image, where the depiction will have to tell a story by way of the glance, by way of the gesture, by way of some kind of visible interaction between people, people and their environment, etc. Everything is narrativized. And of course this has, apart from the effect of being more comprehensible, better understood by the people, has the effect of being better understood by the censor. Besides the emphasis on script, the emphasis on narrative is also conditioned by the need to give the censor something to hold on to in order to review the ideological trustworthiness of the image or the film. You have then, throughout the entire period of Stalinism, this enormous hypertrophy of the script committees in cinema. How many committees the script has to go through before it is even approved to begin to be filmed?! And then of course, once the film begins to be produced, there are additional controls along the way.

As for the langue and parole in Stalinism: this Saussurian dichotomy, it's always been suspect, from the very beginning. What I mean is that you would have, on the one side, clearly separated, just the pure basic elements and the rules of combining them, and on the other side you will have simply the very manifestations of different utterances - this distinction between speech and language - there is something artificial about it. And Stalinism immediately shows why, when you get to the actual functioning of culture and language, it doesn't quite work the way Saussure schematized it. What is immediately clear, when you look at Stalinist culture, is that you begin actually from parole. You begin from these utterances that are given canonical status. They are haloed and sanctified. Eventually, these are simply the utterances of Stalin, but initially there was a repertoire of these. Then these are broken up, and they provide that inventory of elements that would be the langue. Then they are recombined to produce new utterances that in one way or another imitate the original ones. This is, in a very general way, how it works. When you are dealing with actual culture, there is never this zero point that certain linguists try to imagine, where there are just pure paradigmatic elements before they are combined into this or that speech act. No, in Stalinism, it is very clear that you have very rigid speech acts that come first. They are on the altar, and then you have to work with them to begin to compose some kind of language of your own. And this is not true only on the level of verbal language. Every art has its own inventory of canonic texts, plots or images from the past. As time passes, they are accumulated, because now new exemplars are produced. You look at those, and you try to recombine their elements in order to produce you own individual version of socialist realism.

BG: Yes, that is correct, and it is also described by the notion of langage. If you look at French theory, langage as an ideological practice that defines its own position is widely used in the 1960 s and 1970s. But going back to this domination by language: you can escape domination by language in art only if you have an art market. What is an autonomous image? It is an image that has no meaning beyond the fact that I like it, and I like it means 
I'm ready to buy it. Or I do not like it, so I'm not ready to buy. So you have this act of liking/buying or not-liking/not-buying that corresponds to the system of the art market and transcends any possible explanation. If I am asked as a spectator why I like it, there is no obligation to answer the question. This is a condition of the art market. This act of buying transcends any possible language. You like it and you buy it, and you do not have to justify yourself. If you don't have art markets, then you have to justify it. You have to explain why it is good, why it is bad, was it progressive, was it reactionary. If you have to justify, you defer to language. You have two regimes possible for the image. Either it functions as an ideological sign inside a certain kind of symbolic economy regulated by a certain langage as an ideological image, or you have an art market where the image circulates as a commodity. And if it circulates as a commodity, it circulates beyond language, beyond language's control. I don't see another option. There are only these two options. One option was realized in the United States, and the other option was realized in the Soviet Union.

CA: Doesn't the art market and don't art institutions in general use language to legitimize the value of the artworks that are being sold or are part of their collections? Isn't there still a need, even when you have an art market, to use language to legitimize art?

BG: No, of course not. Because if you tell people that it is wonderful, this is an advertisement. It is not a legitimization; it is an advertisement. The fate of the work is not decided through advertisement. The fate of the work is decided by how much money is paid at the auction. This decision to pay money is not necessarily the result of legitimization. You simply decide to pay this money, or you simply decide not to pay this money. You buy this artwork together with everything that was said about it. In the Soviet Union, you do not have this possibility. So, if some commission says the tendency of this work is reactionary, this work cannot be saved by the fact that somebody bought it for a million. That's why the experience of Sotheby's was important for Russian art. People came without any knowledge of Russian art, any knowledge of context, any knowledge of the nation or artist, any knowledge of history. Like when we go into a bazaar in a foreign place, we buy that because we like it and don't buy that because we don't like it - beyond any explanation. There is no explanation. There is no developed language to contextualize that. You simply did like it or you did not like it. And that was a good lesson in the trans-ideological and trans-linguistic sense of art, in art as a commodity that can be completely autonomous from any kind of justification, explanation, or contextualization. I know that people do not like it and intellectuals do not like it. Even artists do not like it. But it is how things are going. And that is the ultimate source of the autonomy of art understood in relationship to language. So this autonomy of art in relationship to language is an illusion. You have only two different kinds of dependencies. You can depend on the art market or you can depend on ideological justifications. Two competing kinds of dependencies.

RB: Stalinist visual culture is ambitiously universal. It presents itself as a universal culture. In the Soviet Union, an empire that encompasses a diverse range of cultures, nationalities, and ethnicities, in addition to spanning eleven different time zones, how do the tensions between the universalism of Stalinist culture and local difference manifest themselves?

BG: I can tell you exactly. It was after the war. The Russian architects, they built Beijing. And they made a project, and showed it to Stalin. It was like Moscow with the same structures and buildings. And he said, "Well, I don't like it. It looks very much like Moscow. If Moscow is going to be Chinese, it must look Chinese. So they put decorative elements on the roofs, and people said, "Ok! Now it is Chinese!" 
PP: Of course Stalin was, in the first Soviet government, the commissar for the nationalities, so we are here at the very source of the problem of how to treat national differences within a universal project. That problem was there from the very beginning. It's very well known that initially the politics of the Soviet state were such that they gave the right to national self-determination to all of those peoples that happen to be within its orbit. That soon became impracticable, and a conflict developed between this kind of local nationalism and proletarian internationalism. In Soviet ideology, these nationalistic aspirations became immediately interpreted as a sign of bourgeois attempts to hijack the revolution. Therefore, you have on one side a politics of self-determination, national selfdetermination, but on the other side you have a resolve not to allow a restoration of the bourgeois order. So, of course, the second position wins, and trumps the first position. The first position remains only on the level of formula, and that formula then, in the cultural realm, is really well known; it's the formula of "socialist in form, national in content." So you, as an artist, are encouraged to have a roof like the one Boris described as long as the main fundamental structure is that of commitment to socialism, but what this in practice means, especially within Stalinism, is that - let's say in painting - you have essentially the same situations reproduced everywhere. But, for example, in Tajikistan there will be a recognizably Tajik landscape, architecture, and faces, and clothing, but it would be more or less the same subject matter that is being depicted.

BG: Huge money was invested in its development of national culture. It was restored, it was taught, and it was investigated, so there was a huge, huge investment in national history and national culture. Whenever they would organize something - it is like the European Union now - it was always dancing. If people are invited to show their cultural identity, they always start to dance.

PP: It's the clearest eruption of national character. If you jump, then the national character has erupted. The moment that this national character begins to bleed onto the level of form - for example, if works from central Asia begin to show in Stalinist times some leanings towards, let's say, ornamentalism or decorative treatment of their subject matter of course then that becomes the same as nationalism on the political level. It becomes the medium for a bourgeois tendency, and essentially ornamentalism is then treated as formalism.

BG: I think it is very important to look at the political side of it. Every Soviet citizen had his or her nationality, and you were identified in the first place by that nationality. There was no general citizenship. You were ascribed a certain nationality. How you were treated in this society was very much dependent on this point. And that, of course, was something that created a lot of national feelings because your experience was part of a national experience.

A second point is that Stalin kept a provision in the Soviet constitution that gives the individual republics the possibility to leave the Soviet Union, and this is, of course, what happened when the Soviet Union dissolved. In the United States, you have the example of southern states wanting to leave the union, and you have a civil war. There is no state in history besides the Soviet Union that had this provision. This was an absolute exception, and this exception guaranteed the peaceful dissolution of the Soviet Union. For example, you didn't have that in Yugoslavia, and that is why you have wars there. This provision was in the Stalinist constitution, and that is why you have no wars there. So the peaceful dissolution of the Soviet Union was actually made possible by Stalin.

CA: But tension was there. It's not as though the individual republics felt that they had the freedom to leave the Soviet Union. 
BG: Of course, but at the moment they could, they used this provision because the provision was there. So you had the legal framework for the dissolution of the Soviet Union at the moment you decide to do that. But there is no such framework for the dissolution of the United States government or India, for example, which is based on the same structure, and you don't have legal frameworks for the dissolution of Yugoslavia. And we know that, you don't have this legal framework, you have a war. What is interesting about the Soviet Union is that it is still very much organized on the principle of ethnicity, and also legally organized in a way that, at the moment of moments, you reap with the sword.

CA: After Stalinism in the absence of its collective project, time takes on a different character. It comes out of joint. Without the certainty of ideology as fate, the Soviet subject finds itself confronted with the possibility that its promised utopian future will not come to be, that existence will not become essence. As part of this reformation, the present, particularly everyday life, emerges as a problematic theme in both official and unofficial cultures offer different accounts of it. How is the awareness of time during the Thaw negotiated in visual culture?

BG: I can remember that, at the beginning, there was a feeling that you can experiment in art and do something different from the socialist realist canon, but at some point in time, as you know, Khrushchev took the side of the bureaucracy and the Union of Soviet Artists, and the Union of Soviet Artists was a very powerful organization. It was not only a decision of the state; the Union of Soviet Artists had immense power to make decisions about art. That meant that everything that was not accepted but the Union of Soviet Artists had to remain in the unofficial sphere, so perhaps this proliferation of non-official art, which was at the same time tolerated but had no access to greater public, so we have a kind of shared space, and all culture from the 1960 s through the 1980 s developed in this space.

PP: The question is probably a little too strongly phrased if we talk about official Soviet culture. It is perhaps difficult to speak of any radical dislocation of time or disorientation in regard to the common project. There are still people alive who remember the Thaw and it's very difficult to judge on the level of the common man what was the reaction. Definitely, the trauma of Stalinism was there and it was experienced, but, I think, at least in the West, this break between the Thaw and Stalinism has been overemphasized at the expense of seeing how much the Thaw in fact is committed to repossessing what Stalinism has tainted. In a way, I find it most useful to think of the Thaw as a kind of moment of repetition, a project of repetition, of how we can have essentially the same project without its distortions, as they called them at the time. So it's a time of purification. It does deal with the past and it does configure time differently. But what strikes me is how much it is still committed to that very same past. Usually, when you think about the Thaw, you think about the return to private life, to the intimate sphere, the return to feeling, sometimes syrupy feeling, sentimentalization, away from the big thoroughfares of history, away from the big gestures, the sloganizing, etc., etc. And all that is there, but we need to see how all that actually serves to reappropriate the same things that were in the slogans. If you look, for example, at films or paintings of the Thaw, there is a great deal of emphasis on these private moments: to find the individual when he is not at work, when he is not storming something, or conquering records. I don't know how many paintings of the Thaw there are with people on smoking breaks. This is a favorite subject. A worker smoking a cigarette, when the tractor is stopped, when the machine is not working. I must have seen at least thirty of these paintings. Why do we apprehend, why do we look for, the person in that moment? Not in order to say that the furnace or the tractor don't matter. No. We look for the person in that moment in order to discover that he is essentially genuine, a deeply beautiful human being, as a private person, and to find in him, and not in the machine, the guarantee that the project will be successful, that socialism has not come out of joint. So the trauma is there, 
but there is also this counter-impulse to heal the trauma, to convince ourselves that things will go on just fine, as long as we discover our true values in the Soviet people, who are still the same. Regardless of what people on the top of the hierarchy did, the ordinary Soviet person is still the moral standard. And you also have, along with this return to the personal, a return to Russia as it always has been. You have, in painting, these portrayals of the countryside, the sleepy village, the wooden hut away from any industrial site or "labor front." But what one searches for in a sleepy Russian village or town that looks like it belongs in the 19th century, is that same old Russian spirit, that spirit that will carry our socialist project forward.

BG: I must say that the Thaw was a huge break in one certain aspect. In Stalin's time, you had no other option to survive other than in the system. You were in the system; there was no other option. After the Thaw, at the end of the 1950s and beginning of the 1960s, you were in a position to choose. You could go and make art in the official system, and then you produce something official. But you can also do abstract expressionism, and some people did that too. So after 1956, you have a different psychological makeup because you were aware of unofficial society. It was not kept from you, but you had to choose it under certain circumstances, and you took a certain responsibility for that. That was a huge point for personal decisions. And you have a parallel; the regime abandoned any communist claims. Their only claim was, "we keep stability and we keep things going." Do not destroy the country - it's as simple as that. I would say a lot of people shared this position. I was also not very happy about the possibility of a crash in the Soviet Union. I think there was a certain consensus about these things. At the same time, I was involved, as were a lot of other people, in movements and groups. There were Buddhist or Hinduist groups, radical Zionist groups, communist groups, Russian fascist groups, and so on and so on. There was a huge plurality of groups. All of these groups had their own system of supply, their own system of support, their own influx of money, their own area of influence. You could survive in these groups; you didn't need the official Soviet system. You had a completely different way of living at that time.

RB: So within art, then, this is also the moment when it suddenly becomes possible to adopt Western modernist styles from the past and to make them in the present in the Soviet Union. So you have Cezanne mixing with de Kooning mixing with surrealism all at once. There's simultaneously different ways of either making art or of living in the social order. How is that negotiated then? How is that navigated? What makes you chose to paint like Cezanne or to paint like de Kooning? Is it purely personal preference? How do you deal with the fact that these are things that Western art history has digested already, but they're suddenly new in the Soviet context?

BG: Well, I think that it's just like in other societies. A couple of days ago, I was in Montreal and in my audience were two or three people who said that they are Jewish and Buddhist at the same time. And then I realized that there are a lot of people in Montreal who have this combination. Why this combination? Because other people have this combination. So you have this opportunity, so if, a lot of other people are doing Cezanne, you are doing de Kooning because a lot of people are doing de Kooning. So that's point number one; that is a principle of the market. Then, you have some friends that are interested in a certain kind of art. You know, it just has this complicated structure and then you just make your way. You look at what you like, and look at the groups that like you; that is also important. And the possibility to survive. The possibility to get money. The possibility to get a position, and so on and so on. So you have all this practical, psychological, ideological texture. And you begin to navigate and look for what comes out of that. Of course, Western culture is controlled by black market. Everything can be bought. You have total access to anything. At the same time, everything is underground. So you have to look at how you organize your life 
and the ways that you can get access to Western publications. So you have all that. And of course it was completely different from Stalin's time. It was psychologically frightening.

CA: So do you see a re-polarization of the present as a result of this kind of moment when you have this matter of choice in the immediate present? Are artists making these choices individually even though they cannot really exhibit their works?

BG: No, I don't think so. That perspective changed, and I think that people had the feeling that they are in the past and capitalism is in the future. I think everybody more or less expected to become capitalists ultimately. Maybe not so soon, maybe not. Maybe not as soon as it happened. Maybe just as soon as it happened. But the feeling was that the Soviet Union was a backwards country, that it is a country that is not modernized the way the Western countries are modernized, that the Soviet Union is isolated from the general movement of ideas and information, and so on and so on. And that makes the country very provincial. And I think there was a complete reevaluation of the present. The present was not a point of transition to a communist future, but it was a point of private or collective accommodation to the modernization processes coming from the West.

PP: Private, especially. The way I always think about the present in the Thaw or the way the present is rendered in Thaw culture is this: the present is the moment of choice, and there is always a sense that you are in some kind of secular purgatory. And the choice is, on a political level, clear: do you stay with Father Stalin or do you go with Grandfather Lenin, who is once removed from you in the genealogical line? So, it's about making the choice of which road to follow. There is also the choice of whether to go the Soviet route or the route of Western temptation, which is thematized in novels of the Thaw period like Ticket to the Stars.

BG: But it's not so certain. Brezhnev made a deep philosophical statement. He said, "Our goal is to come to the present day." He had the feeling that he does not live in the present. The question is, who is living in the present? It is of course the West. So it was for him as obvious as for others. It was obvious that the present has its place outside the Soviet Union, and that to become modern, to become present, to become contemporary, to become up-to-date, we have to look to the West.

I'm not so subjective; I don't think that to be present is to decide something. I'm not so subjective. I think it's a paranoia. Our relationship to the present is a paranoid relationship. We think that somebody, at the time we are sitting here and losing time, somebody will make an achievement that the next day will show itself as a present. Maybe somebody in Tokyo. Maybe somebody else. We have in the present time a feeling of competition. We have a feeling of competition to be modern, competition to be up-to-date, competition to be fashionable. And we have a very good reason to think that the present is not ours. I think that the anxiety of contemporaneity, this feeling that contemporaneity does not belong to us, but maybe to somebody else, is a deep, deep feeling that infects and defines us and our cultures today.

PP: I think that what you said is completely on the mark, except that it applies perhaps to the time after 1964 a little bit better. I didn't live through the Thaw, but it's hard to deny that this very brief period of perhaps ten, perhaps only eight years, in Soviet history still provided a lot of inspiration to keep people within a Soviet frame of mind. The memories of the war were still fresh, and you had the Gagarin flight and various achievements in science. By the end of that period, the Soviet Union loses the nuclear race and everything begins to fall into the pattern that you described of anxiety, cynicism, and the understanding that we have fallen behind, and that every new day takes them further ahead of us. But the Thaw is still full of idealism. I think that the picture you painted is very relevant to the Brezhnev 
time, but during the Thaw, there is certainly still a lot of energy on a mass scale to reappropriate the legacy of the revolution, which had been dragged through the mud in the intervening years. I always found the project of the Virgin Lands Campaign so symbolic this typical Khrushchevian project of sending young people to Kazakhstan to conquer inhospitable, barren lands. I always think of how the campaign functions as a symbolic compensation for the process of collectivization under Stalinism. How can we do collectivized agriculture in a virginal way without the terror, without the masses of peasants who are unwilling and must be forced? We will do it with masses of young people who are enthusiastic and willing to go out into the wilderness and begin from zero. I always think of this as encapsulating the Thaw - again, on the level of official culture - in its attempt to write on a new page, more or less, the same characters that Stalin had inscribed in blood on his page.

BG: It's also a total Americanization. It's the idea of Wild West and conquering.

PP: Certainly, this is the Soviet Wild West.

BG: Yeah, it's completely America. At the point when Khrushchev said that we have to compete with America, of course, we wouldn't win. We couldn't compete with America. This is the idea that never would occur to Stalin because America was capitalist. There is no terrain of competition. At the moment you decide to compete with the West, you are going to lose. That was the decision Khrushchev made, but didn't believe it, yeah? But it was a program of Americanization.

RB: At some point, the socialist realist image loses its affective power. It no longer structures consciousness, stirs desire, or configures intellect. We've traced this a little bit, but perhaps we can go further. How is the Socialist realist image recuperated, appropriated, translated or repurposed by the state during the Thaw period and after. When does its original effect wear off, and what is the fate of the Socialist realist image?

BG: I would say the Socialist realism was never very popular. I was raised in the Soviet Union. It's very interesting that, as a child in school, I was never brought to look at socialist realist paintings - only nineteenth century Russian art. I must say that Soviet power itself didn't trust socialist realism, and the people didn't like it. There was much more nineteenth century culture. If you look at the contemporary Russian population, they almost do not remember socialist realism. Its major authors were never read. What they were brought up on was classical Russian literature and classical Russian art. That was very much in the minds of the people, not socialist art.

CA: I am also wondering about what the situation with socialist realism is in states other than the Soviet Union.

PP: My memories begin even later than those of Boris, and they are even deeper in the same vein. I grew up in the moment when cynicism had already set in, and indeed you were made to study works of socialist realism, but only those select ones that can be put into a narrative of the great world literature or Bulgarian literature or Soviet literature. So this is my memory as well, but if we try to look for some point earlier in history, a juncture that we could point to and say, "Well, this is where socialist realism loses its power" (either on the level of the image or of the text) - that would be an absolutely futile pursuit. You have to start with the question of whether it had power to begin with. It did. It certainly did. But it's so hard to research. It is so difficult to even begin to solve this problem, because, of course, 
if you go and you speak with intellectuals in the former Soviet Union, the kind of people with whom we mostly speak, of course they remember an intellectual environment in which socialist realism never had much reputation to begin with. It was always looked at with scorn and derision. But, in general, the question is a good one. It is perhaps the most important question in Soviet studies. Do ideology or ideological representations, or aesthetic products that are generated within an ideological environment, have a genuine grip on the people?

BG: They did.

PP: When does this grip loosen? All of these are relevant questions, but extremely hard to research and perhaps the way to ask is not when socialist realism had or when it didn't have a grip on mentalities, but to look simply at this long life of socialist realism as a continuous attempt to reinvigorate the rigid official formulas, to give them life and to make them more relevant. And in that context, you can definitely look at the Thaw, at socialist realism of the Thaw, as an attempt to make art, in some way, less formulaic, less normative, and to make it appear as if it is truly a property of those people for whom it is made through humanization, through sentimentalization, through the turn to the private. If you look at Thaw painting, it's not very different from Stalinist art. It's still very rhetorical; it's still very theatrical. But now, we turn to family scenes in which the husband comes back home and is drunk, and this is something to which people at the time responded avidly. Yet the technique of painting had not changed too much.

BG: Officially not, as I said. But you have different options at the same time. You have change. But I think what's important is that you have different options. You have a flood of French movies. You have a flood of translations also from avant-garde. So you have simply different options. You do not look in the same direction anymore because you have different options. You didn't have those options in Stalin's time.

CA: Since the fall of communism, a dominant temporality in Russian culture has been a form of nostalgia, though there are many forms this nostalgia takes. For Russia's nouveau riche, it takes the form of the Triumph Palace in Moscow, a massive apartment complex that, in a postmodern fashion, quotes Stalinist architecture. For those whose fate has proved less fortunate since the fall of communism, it proves to be a form of melancholic longing for the securities of the communist past. For the genuinely revolutionary, it provokes a desire to restart the communist project. And another form of this would be ostalgie, the commodification of nostalgic objects from communist times for the sake of profit. How do these nostalgias compete in the postcommunist context, and how they are they situated in relation to one another? Also, do we have ostalgie in countries other than the German Democratic Republic, with which the concept has been closely associated?

BG: In Russia, everything is all about money. It's really all about money. It's through and through a capitalist country. People are thinking only about money. You have mass culture because mass culture satisfies people's tastes. It's not about nostalgia; it's about the taste of the huge masses of the Russian population. People just like certain commodities and that kind of architecture or this kind of image. They like it because it's available. At the same time you have a luxury market. I don't know if you have been to Moscow recently. The whole center of Moscow is a huge boutique. And you have a lot of modernist architecture. You have everything that people are ready to pay for. You have a huge investment in contemporary art. Every month there are new projects and new spaces for contemporary art. A certain stratum of the population is pouring millions and millions into contemporary art. Everyone who was a dissident at one time is now an artist. You have this development, which is probably not characteristic of all Eastern Europe because people simply do not have this kind 
of money. If you go to another Eastern European country, I think the big difference is that they live on Western money. The contemporary art scene lives through projects of the European Union.

If you look at the nostalgia in Germany, the problem is that reification was a completely economical, political, and cultural takeover. In the other countries of Eastern Europe, the ruling class, the former ruling class, and also a big part of the Russian population, profited immensely economically from the change to capitalism. This didn't happen in Eastern Germany because Western Germans took all the high-ranking positions. Because of this, there is ressentiment and nostalgia that is very different in the Eastern Germany situation because it was like colonization. But in the other states like Romania, Poland, and all the former Soviet republics, they developed a very ardent form of nationalism. Whatever problems they have, economical problems and so on, they can compensate ideologically through their nationalist discourse: "even if we are suffering, we are independent and we are free from the Russians," so "we are happy even if we are poor." We have a powerful new ideology for Eastern Europe. We don't have that in Russia because it is very capitalist; it is like China to a degree that I think you don't have otherwise in Eastern Europe. Especially, you do not have this complete capitalistic change, like a complete shift. So, I think that's the cause. I think nationalism is a driving force of all the Eastern European countries.

CA: But nationalism existed within communist regimes in Eastern Europe even before all this. For example, communism in Romania and nationalism were very strongly interlinked. I agree that there are strong nationalist tendencies in the postcommunist context, but nationalism was already part of the project of communism.

BG: Nationalism was part of the communist project. All the states like Estonia were artificially created by communists who expelled Germans. For example, the populations of the Baltic States were actually rural populations; Germans lived in the cities. So you have all these national states as long-term effects of Eastern Europe history. In recent decades, you have nationalism as the legitimization for economical problems. It is the explanation for why you have to endure problems, and that explanation was once a communist one: "you have to endure it because we are building the economy." And now the explanation sounds like, "we are free from Russian imperialism, and we are free to build our own national state and our cultural identity." That is the explanation for why you have some temporary economic difficulties.

PP: And as soon as that explanation is offered, then the time comes to join the European Union, and new explanations are in order. It is no longer nationalism, but the need for integration. Because we need to integrate, we need to accept the rules and strictures of the European Union, so now you have the situation in which Greece is basically blackmailed into starving its people in order to be in the European Union. That's the upgrade to nationalism, or the next fate of nationalism.

But regarding nostalgia, I would definitely say that it's not the only or even the most important framework in which to think the past from the present, either in the Soviet Union or in Eastern Europe. There are definitely people still, despite the rule of capitalism in Russia, in intellectual circles, though not only there, who are trying to take serious account of Stalinism and to keep it, to preserve it as the trauma that it is, and to write it into history. These people do not get celebrity status and do not get the same exposure as pop stars, but they are there. This attempt is definitely not something you can call nostalgia. There is also the statist appropriation of the past, which is also in no way nostalgic. It is simply the reclaiming of a usable past that can be written into the history of great Russian nationalism, and it is not very different from what Stalin himself did in regard to previous pasts. We see now the rewriting of history, also not at all within the framework of nostalgia. Then, there is 
the commercial aspect Boris was talking about: this rampant commodification of Stalin, which again does not fit the rubric of nostalgia at all. It is simply making money, whether it is by having a restaurant in which you are treated rudely by Soviet-looking waiters or whether it is by selling all sorts of Stalinist-era tchotchkes. That also does not go under rubric of nostalgia, simply because there is no emotional investment at all. Perhaps there is some emotional investment on the part of the consumer - obviously you buy posters of Stalin and you hang them in your living room because there is something there that strikes you as cool - but that is hardly deserving of the name nostalgia. And also there is the sense in contemporary Russian consciousness that, "yes, we did have a twentieth century that was very different from what most other modern nations had." And that feeds certain old ideas of exceptionalism, which are very deeply rooted in the national psychology. This gives them new fuel. On the brighter side of all this is the fact that there are many people in Eastern Europe who feel anxious about capitalism completely dominant and without any alternative, so the memory of a world that was a little different, whatever its defects and horrors, could have some energizing potential. But it is very hard to see how exactly such a potential could be utilized, how to shape it into anything useful for the left or how to make of it anything that would be a usable present. I personally don't see how this can be done.

BG: I believe that the only kind of nostalgia that people have, and I agree with Petre, is a kind of exceptionality. Russians feel completely exceptional; they've always felt this way, and they feel this way still. Of course, they are also irritated that other people treat them as being exceptional, so there is some ambiguity. You have this capitalism in Moscow that resembles a "cheese for free" sign on a mousetrap. This is the capitalist heart, and it's very obvious to everyone.

PP: Clearly, this must be very depressing for a lot of people, but also especially for a lot of people for whom communism was their entire life. So, nostalgia is there, if you want to call it that; what kind of social or political effectiveness it has is hard to say. Certainly some of the resentment is channeled to new imperial ambitions and neo-Stalinist ideologies, but I personally would like to see some kind of actual radical use of that energy of resentment.

BG: The art world is completely dominated by the left right at the moment. All the groups are radical and partisan. Everybody is like that.

PP: But that, in a sense, is also a depressing moment for Marxists because it shows the commodification of left politics as well.

BG: It's complete commodification. Of course, it is complete commodification. But Russia is always interesting because it's always radical. Whatever is done is done one hundred percent. It is one hundred percent commodification. And you look at that, and it's fascinating!

RB: Perhaps we have time for one last question, which you've already gone a long way towards answering. The question is whether postcommunism is really the best term for periodizing the Russian present. It seems clearly that it is not, particularly because this temporality of the post-, whether it is postmodern or postcolonial, ends up locking the present into a kind of retrospective gaze so that postcommunist countries are fixated on their past, the question is whether enough time has passed to situate communism in the past and therefore to move onward in some other way. As long as this question continues to be asked it can never really be answered in the affirmative; you're trapped in the past. With so much attention devoted to the past and present the connection of the present to the possible futures is not really sufficiently examined. Capitalism proceeds onwards, and absurd 
fantasies proliferate. What kind of future does postcommunism or the Russian situation at the present promise?

BG: I don't think that postcommunism is not a good description because, if you want to export something, you have to export something. What do you export in the capitalist context right now? Russian postcommunism. And the question is how long Russia can export postcommunism, and that is a very open question. Actually, at the moment, it can only sell that. Germany sold it for 45 years, a very long period of time. But, in fact, Germany still sells National Socialism. If you have these historical resources, it is hard to escape them, hard not to use it, sell it, package it, and export it. Russiannness as such is not interesting for foreigners, but people are interested in communism still. I don't see, in the foreseeable future, at least from my perspective, that this postcommunist condition can change. I simply don't see it.

PP: We have to think of this "post-" as the place of contest. Are we going to push off the Soviet past and start asking what it has done to us, or are we going to be locked into it, as you say in your question? This is the place of debate and there are people who don't want to let it go, and do not want to imagine a new future in which capitalism takes over and everything simply becomes a little bit more exotic version of the tourist attractions that you can find everywhere. There is no Eastern European capital that does not have a communist tour, for example. So Russia, in that sense, simply becomes the most authentic sort of a communist theme park. But of course there are people in Russia who don't want it to be that. There are those who want to be postcommunist, and who want to make sense of the present in those terms. Then, there is the objective situation, which simply by bringing up new generations and locking Russia into the present-day global world make the past, with every day, less and less relevant. There are students now graduating from Russian schools who couldn't care less about Stalinism.

BG: I don't see that as a Russian problem.

PP: No, no, it's not a just a Russian problem.

BG: I see that as a Western problem. The West obviously does not want to integrate Russia for many reasons. I don't think that the West is interested in expanding beyond Eastern Europe into Russia. I don't think that the West is interested in debate with Russia. It seems to me that this kind of military or political isolation that Russia has in relation the West now will not be changed in the foreseeable future. That means that Russia will reproduce its old form, all the structures that it has always had. Because it has always been, since the eighteenth and nineteenth century, in the same position: it was not integrated in the international political and military system. Maybe in the 19th century, but even then not really. If the basics remain the same, nothing changes. I don't see any fundamental change in the Russian position in the world.

PP: From the point of view of Russia, I agree with you. I'm not sure whether there is something like complicity on the part of the West to not integrate Russia. I am not sure about this, and I don't see how that argument could be made. To end in our own backyard: if you look at how Russia is treated within American universities, you will definitely see that there are definite investments in keeping Russia as other as possible, as different, as exotic as possible. And from that angle, there are obviously quite a few people who are making symbolic capital and making a living out of presenting Russia in such a way. 
BG: Look at mass culture; look at the episode of 24 that I saw yesterday. The bad guys seemed to be Iranians, but the Russian government was behind them; it only looks like the bad guys are Muslim terrorists or whatever. Ultimately, it is Russia that the West fears.

Russia is still not part of the Western military and political system. Whoever is responsible for that is a separate question. I would say that, if a certain geopolitical reality is reproduced, then the reaction to the social and geopolitical reality is reproduced because this reaction is also a reaction to a fact that Russia is de facto not part of the military and political alliance. It's not a problem of responsibility; it's simply the fact that certain basic realities didn't change, I would say. Some change from communism to capitalism, so economic relations are different, but the political and military situation hasn't changed, and the military and political constellation is more important for culture than the economic one because if you have some kind of military and political isolation, you have to justify it in cultural terms. You have to deal with culture to create an identity. I don't believe very much in psychology. I am a Marxist, I believe in the base and culture as superstructure. 


\section{(cc) EY-NG-ND}

This work is licensed under a Creative Commons Attribution-Noncommercial-No Derivative Works 3.0 United States License.

\section{ULIS D-Sork}

the University of Pittsburgh as part of its

This journal is operated by the University Library System of D-Scribe Digital Publishing Program, and is co-sponsored by the University of Pittsburgh Press. 